\title{
Martian gullies tempt NASA to look for water
}

Michael Milstein, Wisconsin

Two strategies of the US space agency NASA may at last have paid off. A 'better, faster, cheaper' mission that also uses the 'follow the water' approach to Mars exploration has turned up what look like gullies freshly sculpted by water on frigid martian slopes where no liquid water should be.

At a news conference called hastily in Washington last week after word leaked out of a paper in the 30 June issue of Science, a team of planetary geologists studying images from the Mars Global Surveyor displayed sharp aerial photographs of red-rock washes and winding channels on the planet (see right). These features are strikingly reminiscent of deserts in the American southwest.

In some cases, the gullies cut through or blanket modern martian features such as sand dunes, suggesting that they formed very recently. If the photos shown had been of Earth instead of Mars, the scientists said, there would have been no doubt that water had carved the features.

"There's still a finite chance that they were formed some other way," said Michael Malin, head of Malin Space Science Systems, Inc., which built and operates the eagle-eyed camera aboard the Mars Global Surveyor. "But there's a high probability that they were formed by water."

In one fell swoop, the revelation has established compelling new scientific targets and generated renewed enthusiasm for what had become a rudderless NASA Mars programme beset by the loss late last year of two major missions, the Mars Climate Orbiter and the Mars Polar Lander.

At the same time, it appears to vindicate NASA's 'follow the water' strategy for Mars exploration, in which the agency has aimed to investigate the sinuous canyons and possible shorelines that may offer evidence of water in the planet's past, and which may be the best place to look for signs of martian life.

Ed Weiler, NASA associate administrator for space science, was quick to point out that the Mars Global Surveyor had been launched in 1996 under the same 'better, faster, cheaper' mandate that was now being blamed for fatal oversights in the navigation of the Mars Climate Orbiter and the design of the Mars Polar Lander.

"I'm just hoping the news today will pass the message that our Mars programme is not dead, in spite of all the rumours of its death a few months ago," Weiler said last week. "It is very, very pleasing to be talking about something positive for a change."

NASA must decide by July whether to send an orbiter or a rover to Mars in 2003. Malin, whose stock is sure to rise with these latest revelations, favours an orbiter with an even higher-resolution camera than on the

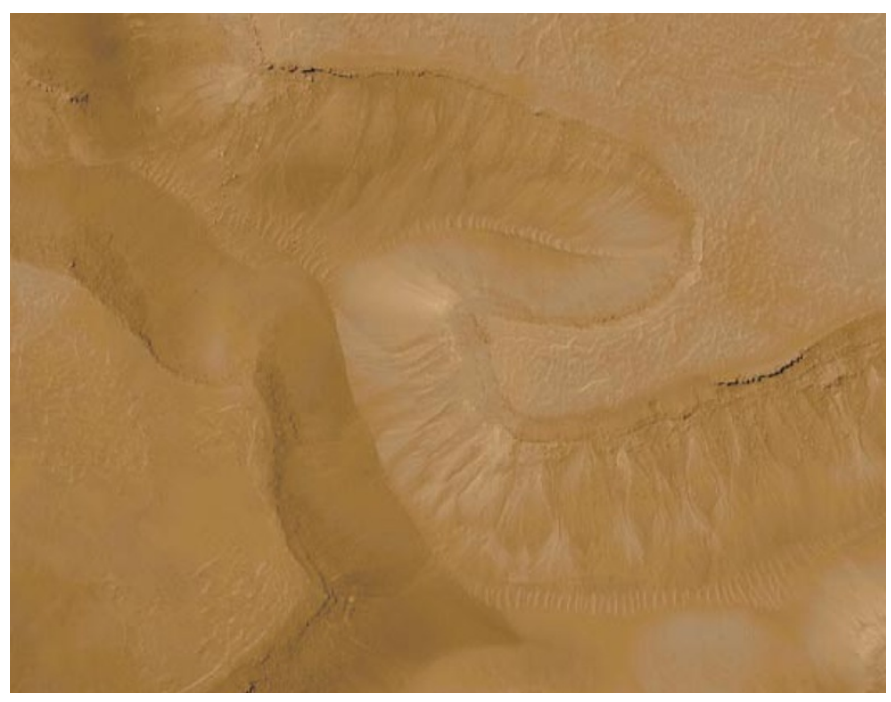

Water mark? Images from the Mars Global Surveyor appear to show gullies cutting through sand dunes.

Mars Global Surveyor; others now argue for a rover to follow the water on the ground.

Following the water on Mars may prove much easier than researchers had imagined if water is indeed emerging on the planet's cold, arid surface. Malin and co-worker Kenneth Edgett found about 120 places where water appeared to have gushed from the walls of impact craters, pits and large valleys.

Almost all of these are in the polar regions, usually on slopes shaded from the Sun. This places them in the coldest martian regions of all, where temperatures drop to $-100{ }^{\circ} \mathrm{C}$, and where liquid water might seem least likely to appear.

But the two researchers say the cold may actually help by freezing dams of ice in place at the surface. Briny water building up behind the dams might finally burst out in torrents that then scour gullies in the slopes below before quickly vaporizing.

Many gullies end in what the researchers called 'aprons' of sediment. These sometimes cover up modern sand dunes and lack impact craters, signs that they are "incredibly new" and may still be forming today, says Edgett.

But not everyone is convinced. Michael Carr of the US Geological Survey, who has spent decades looking for signs of water on Mars but is not part of Malin's team, says that water appears the most ready explanation. He adds that bursts of gas might also lubricate debris flows, and cautions against leaping to earthly conclusions on a different planet, especially one where water would not be expected to persist.

"Water is so difficult to understand, given the physical conditions on the surface of Mars, and we know those physical conditions very, very well — it's just simply too cold," says Carr. "I'm just having trouble reconciling the observation with the interpretation."

http://www.msss.com/mars_images/

\section{Astronomers fume over night light}

\section{Bill Triplett, Washington}

This autumn, the main thing astronomers in part of the Washington area will see through their telescopes is irony. Discovery Communications, the parent company of the cable television channel specializing in science-orientated programmes and which sells telescopes in its shops, is planning to build a new global headquarters - with an illuminating twist.

The intended site is at Silver Spring, Maryland, not far from the Washington headquarters of the US space agency NASA. And the most prominent feature of the new building will be a 300 -foot tower shooting a powerful beam of light into the night sky.
That is intolerable, say the area's astronomers, who are increasingly sensitive to the issue of 'light pollution', and are bemused that Discovery does not seem to be. "Isn't part of their charter to promote science and protect the environment?" asks Bob Gent, public affairs officer for the International Dark-sky Association (IDA). "Yet here they are destroying the night sky and ruining astronomy."

The night sky above the US capital is steadily deteriorating, as it is over most major cities around the world. "Light pollution in Washington is becoming more of a topic of concern for everyone," says John Settle, president of the Greenbelt 


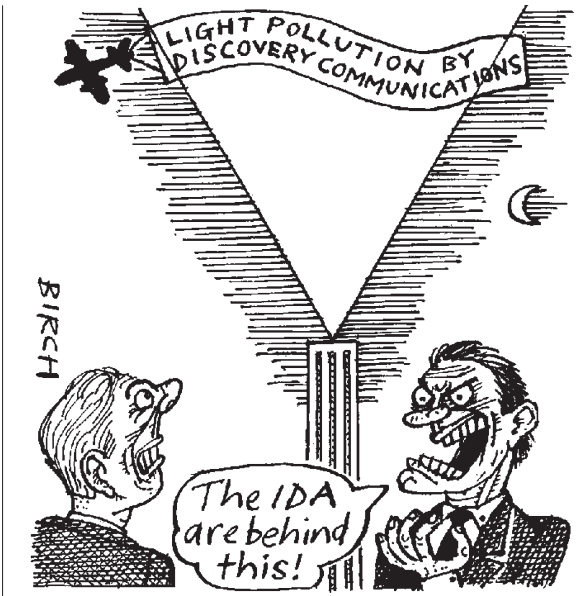

Astronomy Club, an amateur group in Greenbelt, Maryland, which is near Silver Spring. "This is probably the second most polluted area [in the United States] after New York City, and this light will only degrade the quality of life for everyone around here. Its only purpose seems to be an ostentatious display of corporate power," he says.

Settle says that in the Greenbelt area, which is also home to an astronomy club composed of employees at NASA's

Goddard Space Flight Center, star-gazers can see only second-magnitude stars. Spotting fifth- or sixth-magnitude stars, he says, needs more than an hour's drive.

There is no major astronomical research left in the Washington area, and the US Naval Observatory moved its heavy equipment and operations to Arizona more than $\mathbf{4 0}$ years ago.

Geoff Chester, the observatory's spokesman, questions the reason for the planned tower light: "Why would anyone want to waste photons for something that's just going to light up the bellies of airplanes?" However, he doubts whether it will have much impact on the observatory's small-scale work.

But Gent says he has heard numerous complaints, not only from amateur astronomy clubs. "The American Astronomical Society has contacted me. So has the University of Maryland astronomy department," he says.

David Leavy, spokesman for Discovery Communications, says he is unaware of any complaints except for one letter from the IDA. But he admits that a recent article in a local paper about the plans for the building has made the company sensitive to the concerns.

So far, he says, no changes have been made to the design. "But as we go forward we'll be consulting with the organizations to make sure this structure is something... that will be environmentally sound and will not cause any celestial inconvenience." Rest assured, says Gent, the IDA will be watching.

\section{Educated US public get more wary of genetic engineering}

Paul Smaglik, Washington

Well-educated Americans have become less keen on genetic engineering over the past five years, according to a survey carried out by the National Science Board (NSB). This is despite a general increase in acceptance of the topic in the previous decade.

The proportion of US adults with bachelor degrees who responded that the potentially harmful results of genetic engineering either 'slightly' or 'significantly' outweighed the benefits is rising, from $20 \%$ in 1995 and $24 \%$ in 1997 to $29 \%$ in 1999.

The results, published last week in the NSB's Science and Education Indicators 2000, point to a growing suspicion of the biotech industry by some sectors of the public, at a time when the industry, prompted by the full sequencing of the human genome (see page 983), is set for greater financial prosperity.

Negative perception of genetic engineering across all US adults has remained sightly less volatile. Adults with less than a college education are still more suspicious of genetic engineering as a whole, while adults who have completed high school or college or who follow progress in medical research have become more suspicious of it since 1995.

But some are sceptical. Dan Eramian, spokesperson for the Biotechnology Industry Organization (BIO), says it "runs counter to every national survey I've seen".
Eramian says the public has little idea of what 'genetic engineering' means. The term encompasses cloning, gene therapy and genetically modified (GM) foods, among other transgenic technologies. Those polled may have responded differently if they had been asked about each specific technology, according to the report.

But Jeremy Rifkin, president of the Foundation on Economic Trends in Washington, a group that opposes GM foods, says that the more BIO promotes the applications of genetics to promote its image, the more people appear to become opposed to it.

Rifkin thinks that the falling support of genetic engineering by educated and informed people reflects uncertainty, rather than panic. "People are saying we don't have enough information to show that this is safe," he says.

Dorothy Nelkin, a professor of sociology at New York University who specializes in science and law, says she is not surprised at the results. People in grass-roots organizations who oppose GM food, she says, tend to be both highly educated and informed of progress in science and medicine.

Nelkin suspects that the public fears industry taking over science more than it fears the science itself. "Commercialization enhances mistrust," Nelkin says.

| http://www.nsf.gov/sbe/srs/seind00/start.htm

\begin{tabular}{|c|c|c|c|c|c|}
\hline \multicolumn{6}{|c|}{$\begin{array}{l}\text { Respondents who argue that the harmful results of genetic engineering 'slightly' or 'strongly' } \\
\text { outweigh benefits }\end{array}$} \\
\hline & 1985 & 1990 & 1995 & 1997 & 1999 \\
\hline All adults & 39 & 37 & 35 & 36 & 38 \\
\hline Male & 35 & 34 & 32 & 21 & 33 \\
\hline Female & 42 & 41 & 38 & 40 & 42 \\
\hline Less than high-school graduate & 36 & 32 & 42 & 44 & 36 \\
\hline Baccalaureate and higher & 31 & 28 & 20 & 27 & 26 \\
\hline 'Attentive' to medical research & 36 & 30 & 27 & 30 & 36 \\
\hline
\end{tabular}

\section{Call for more accelerator research}

Quirin Schiermeier, Munich

Luciano Maiani, director-general of the Geneva-based European Laboratory for Particle Physics (CERN), last week called on the organization's 20 member states to put in place a "vigorous programme of accelerator research and development" to help maintain CERN's leading position in particle physics in the long term.

CERN's current core activity, the search for the still elusive Higgs particles, will continue, Maiani told the CERN Council last week. Higgs particles, if they exist, are predicted to be in the range of CERN's new Large Hadron Collider (LHC), experimental work on which is to start next year.

But funding for future work, including the Compact Linear Collider (CLIC) and research into high-intensity proton accelerators aimed at producing a secondgeneration neutrino beam, is "barely sufficient", he said. These projects currently receive around $1 \%$ of CERN's resources. This was acceptable during the construction phase of the LHC, Maiani said, but now "it is time to start a gradual increase". 